\title{
ANAESTHESIA FOR AMBULATORY SURGERY
}

\author{
Jean-Paul Dechene
}

\begin{abstract}
ANAESTHESIA FOR AMBULATORY SURGERY is anaesthesia for patients who are not admitted to hospital. In most Western countries the reduction in the number of hospital beds, shortage of nurses, a desire to decrease the cost of medical care and to foster participation of the family in the process of maintaining health have served increasingly to develop this type of surgery within the general hospital setting.

The object of this paper is to review problems inherent in the implementation of anaesthesia for ambulatory surgery at the Jewish General Hospital in Montreal and to relate our experiences with Alfathesin and enflurane (E $\bar{E}$ thrane) as general anaesthetic agents for out-patients.
\end{abstract}

The ambulatory surgery service as a special unit'

Because of lack of space, particularly in the accommodation of a separate recovery room, the anaesthesia service for ambulatory surgical patients had to be more or less completely integrated into the facilities for in-patients. Nevertheless, a separate administrative organization was established with its own diagnostic unit, consisting of laboratory and radiological facilities and its own pre-anaesthetic consultation service. Patients were evaluated by three physicians working on a part-time basis; these were a surgeon, a paediatrician and, of course, an anaesthetist.

A special-care unit consisting of 27 beds was created to take care of patients scheduled for ambulatory surgery, from the time of their arrival to discharge. In the absence of separate surgical facilities, an operating room was reserved for ambulatory surgery within the hospital's regular operating suite. Patients shared recovery facilities with in-patients and hence the same criteria for evaluation were used for both groups based on the "Aldrete" formula. 12 Upon discharge from the recovery room patients were returned to the ambulatory care unit, where they were observed until discharge from hospital.

Jean-Paul Dechene, M.D., F.R.C.P.(C), Medical Director, St. Joseph Hospital, Rimouski, Quebec. Lately Anaest hetist-in-Chief, Jewish General Hospital, Montreal, Que.

\section{Selection of patients}

While selection of patients remains a surgical responsibility, it must conform with the rules and criteria established by an especially established hospital committee on ambulatory surgery. These are rules are:

1. The patient He must be prepared to accept treatment on an ambulatory basis. He must be in good health or, failing that, any systemic disease must be well controlled. In a few instances physicians may accept patients with more serious systemic disorders because admission to hospital might constitute a greater potential risk than management on an out-patient basis. Such might be the case in a patient suffering from leukaemia exposed to the risk of cross-infection in hospital.

2. Type of operation. Operative procedures not exceeding 90 minutes in duration are best suited for out-patient anaesthesia, provided that they are associated with minimal bleeding and only minor physiological derangement. The bulk of these operations are interventions on superficial structures. Patients with infection are rarely considered because of the need for separate facilities and additional nurses for post-operative observation. Emergency cases are not suited for outpatient management because it is more difficult to evaluate these patients, and their acceptance would disrupt the elective operating schedule. Although tonsillectomies have been done on an out-patient basis, there is no general agreement whether they are suitable or not.

3. Anaesthesia. The first choice of anaesthesia for ambulatory surgery is obviously a local or regional technique when applicable. If general anaesthesia is needed, it is suggested that the newer agents like Alfathesin and enflurane should be seriously considered.

4. Time. In many settings, including our own, it has been found advisable to carry out ambulatory surgery in the mornings or, at the latest, in the early afternoon to permit post-operative observation for periods of two to six hours.

5. Recovery. Rapid uncomplicated recovery from the anaesthetic is mandatory.

\section{Pre-operative Evaluation and Instruction}

Pre-operative evaluation and instruction is 
most often done in advance of admission. Evaluation should include such basic laboratory data as a complete blood count, urinalysis, electrocardiogram and chest film. In most instances specimens are analyzed in our own out-patient facility, but results from accredited outside laboratories are accepted as long as they comply with hospital or provincial requirements. Such reports should not date back more than 30 days, the average being 14 days. Some paediatric institutions do not require a routine urinalysis before operation and request it only in cases where there is a history of genito-urinary disease.

The need for additional tests is determined by age and physical status. Written instructions describing the pre-operative admission and recovery periods are supplied to the patient in advance. These include the following instructions to the patient:

\section{A. Before operation}

1. Do not take food or drink after midnight preceding the day of operation;

2. Notify the surgeon of any change in physical condition, such as a cold, fever, etc.

\section{B. After the operation}

1. Arrange for a responsible adult to accompany you home;

2. Do not use public conveyances unless accompanied by a responsible adult.

3. Do not ingest alcoholic beverages, drive a car, or operate complex machinery for the first 24 hours after the operation;

4. Do not make important decisions until full recovery has taken place.

In order to protect both physicians and the hospital these instructions should be explained to the patient, signed by him and witnessed before anaesthesia or sedation is administered.

\section{Anaesthesia for ambulatory surgery}

Premedication. Only minimal pre-anaesthetic medication should be used: ${ }^{2-4}$ it may be either omitted altogether or any medication given should be minimally depressive and devoid of secondary effects. While we are no longer using premedication for ambulatory surgery in our practice there still remains room for exceptions. Unless it is contra-indicated, atropine alone is usually administered in those cases in which general anaesthesia is planned.

The anaesthetic. In ambulatory surgery local or regional anaesthesia is the first choice if it is applicable. This applies especially to operations on the extremities. In work on the upper extremities intravenous regional analgesia is particularly indicateds because of the rapid disappearance of its effect shortly after removal of the tourniquet. General anaesthesia for out-patients should provide rapid induction and emergence with minimal post-operative depression and vomiting.

Recovery. Discharge from the recovery room is based on "street fitness' or the ability of the patient to leave the hospital safely in the company of a responsible adult. Consciousness, rational behaviour and ambulation do not imply full recovery. Patients who "act and feel fine" may not score well on a driving test while patients who feel sleepy may drive normally. Blood pressure and pulse may return to normal while residual myocardial depression remains. In the past, different methods have been used for the objective evaluation of patients during the period of recovery but at the Jewish General Hospital the "Aldrete method" $" 12$ is now being used for evaluation of various parameters and is first applied on arrival of the patient in the recovery room and repeated at intervals of $\mathbf{3 0}$ minutes until the patient is discharged. Five parameters are recorded, namely motor activity of the extremities, respiration, circulation, consciousness and colour of the skin. A maximum of two points is allotted for each and discharge from the recovery room is authorized only when a score of 10 is reached. The only exceptions to this rule are patients who are transferred immediately to the intensive care unit. Figure 1 reproduces our protocol and includes the criteria for assignment of values. At the Jewish General Hospital this sheet is a compulsory part of the anaesthesia record. Where doubt exists, specific psychomotor tests such as the Newman, Horatz and Bourdon tests are applied to complete the evaluation before discharge from the recovery room is authorized.

\section{Personal Experience}

The following is a summary of our experiences with enflurane in children and Alfathesin for general anaesthesia for ambulatory surgery, in adults.

\section{Enflurane for ambulatory surgery in children \\ Experience with enflurane in ambulatory surgery in children is largely related to ophthal- mological procedures: 181 of a total of 274 anaesthetics were for eye operations and the majority of these (122) were in children under 10}


RECOVERY ROOM EVALUATION

\begin{tabular}{|c|c|c|c|c|c|c|c|c|c|}
\hline MODALI TY & SCORE & CRITERLA & ARRIVAL & $30 \mathrm{~min}$. & $60 \mathrm{gln}$. & $90 \mathrm{~min}$. & $12 \mathrm{~min}$. & 150 outn. & $180 \mathrm{~min}$. \\
\hline ACTIVITY & $\begin{array}{l}2 \\
1 \\
0\end{array}$ & $\begin{array}{l}\text { moves } 4 \text { extremities on command } \\
\text { moves } 2 \text { extremtites on command } \\
\text { moves } 0 \text { extremities on command }\end{array}$ & & & & & & & \\
\hline RESPIRATIOA & $\begin{array}{l}2 \\
1 \\
0\end{array}$ & $\begin{array}{l}\text { deep breathing - cough } \\
\text { dyspnoea or linited tidal volume } \\
\text { apnoes }\end{array}$ & & & & & & & \\
\hline CIRCULATION & $\begin{array}{l}2 \\
1 \\
0\end{array}$ & $\begin{array}{l}B P-/-20 \% \text { of preanaesthetlc } \\
B P-20 \%-50 \% \text { preanaesthet1c } \\
B P-50 \% \text { preanaes thetic }\end{array}$ & & & & & & & \\
\hline CONSCTOUSNESS & $\begin{array}{l}2 \\
1 \\
0\end{array}$ & $\begin{array}{l}\text { fully awake } \\
\text { arousable on verbal commend } \\
\text { no responding }\end{array}$ & & & & & & & \\
\hline COLOUR & $\begin{array}{l}2 \\
1 \\
0\end{array}$ & $\begin{array}{l}\text { plnk } \\
\text { pale, dusky, bloc chy } \\
\text { cyanotic }\end{array}$ & & & & & & & \\
\hline TOTAL & & & & & & & & & \\
\hline
\end{tabular}

COMERTS:

RELEASED GY ARAES. DEPT, :

FIGURE I Protocol for evaluation of patient recovery in the post-operative recovery room.

years of age. The most common procedures were correction of strabismus, lacrymal duct probing, aspiration of cataract, removal of chalazion and enucleation of an eye. The remaining 93 cases include tooth extractions, circumcision, repair of hernia, orchidectomy, orchidopexy and tonsillectomy, again frequently in children under the age of ten years. Premedication was either omitted entirely or consisted of atropine alone. Enflurane was administered by means of an Airco enflurane vaporizer through the Jackson-Rees modification of the Ayre T-piece. Duration of these procedures was from 20 minutes to two hours, with an average of 85 minutes. As far as recovery is concerned, in the entire group only 5.5 per cent reached a score of 10 of the Aldrete scale upon arrival in the recovery room. Of the ophthalmology group only 52 per cent were fully awake after 30 minutes, 33 per cent took more than 60 minutes for recovery and 8.5 per cent more than 90 minutes. Of the second nonophthalmology group, 41 per cent required more than 60 minutes and 5.5 per cent more than 90 minutes for full awakening. It was concluded that enflurane did not demonstrate particular advantage over similar agents such as halothane as far as recovery is concerned and, in this regard, we concur with the conclusions of Steward ${ }^{6}$ and others. On the other hand, good intra-operative cardiovascular stability was very noticeable in the series of eye cases. According to Kim, Smith and Jenkins, ${ }^{7}$ enflurane is a useful anaesthetic in eye operations because it does not increase intra-ocular pressure. Indeed we found that it decreased it moderately in 80 per cent of cases. Moreover, enflurane was chosen in preference to halothane because of the rare chance of severe and potentially fatal post-operative liver failure with halothane.

\section{Alfathe sin by infusion in adults}

By December 1977, 600 anaesthetics had been administered to out-patients at the Jewish General Hospital using Alfathesin by infusion together with fractional increments of pentazocine (Talwin). ${ }^{8}$ The outstanding property of this technique has been the virtual complete absence of side-effects, making this technique the most suit- 
able for out-patient surgical procedures. In contemplating the advisability of continuous infusion it was necessary to consider any possible cumulative effect of the drug. It is known from the work of British researchers ${ }^{9}$ that, following intravenous injection, the plasma concentration of Alfathesin drops quickly after an initial peak, the half-life of the agent in plasma being seven minutes. Serum protein binding is weak, although studies in animals have shown an affinity of Alfathesin to albumen and beta lipo-proteins. The distribution of the two constituents of Alfathesin is similar to other steroids and no particular affinity in distribution to fatty tissues has been observed. Both undergo metabolic degradation in the liver by combination with glycuronic acid. The lack of cumulative effect was confirmed by our own observations in that no reduction in successive doses of Alfathesin was necessary, or indeed possible, with the intermittent injection technique which had been used originally. It may be worth repeating that, although Alfathesin is a mixture of two steroids, it has no antiinflammatory, mineralo-corticoid, oestrogenic or progestational activity. In view of these facts we felt justified in attempting the continuous infusion technique.

Pencazocine. The absence of analgesic properties of Alfathesin made it imperative that another agent be added to provide analgesia. In Europe ${ }^{10}$ this aim was achieved primarily by the use of detromoramide (Palfium) or by fentanyl (Sublimaze). Since we were more familiar with pentazocine, it was decided to use that agent to achieve the desired analgesia. We were reinforced in this decision by a number of studies which have demonstrated its advantages. "I

\section{The infusion study}

The combination of continuous Alfathesin with intermittent pentazocine has been used in over 600 cases, although only the first 409 have been analyzed in detail. The majority of patients were in the 21- to 30-year age group and the 61- to 70 -year age group.

This age distribution is explained by the selection of our patients. The younger group consisted primarily of minor gynaecological procedures, such as dilatation and curettage and breast biopsy, while the older group consisted primarily of eystoscopies and transurethral resections of the prostate. Sex distribution was approximately even with 201 males and 208 females, and operations lasted from 15 to 20 minutes. Premedication in this group was with atropine alone or atropine together with anileridine (leritine) in the earlier cases, while later no premedication at all was given.

\section{RESULTS}

In analyzing our results, the following facts emerge: the Alfathesin infusion technique combined with pentazocine provides adequate light anaesthesia with analgesia and is followed by complete and rapid recovery. In this respect it is superior to the majority of other techniques for anaesthesia in out-patients. All patients were coded in the recovery room by the Aldrete method. ${ }^{12}$ A number of them, selected at random, underwent psychomotor tests. ${ }^{13}$ The following data demonstrate the superiority of the continuous infusion technique over intermittent injections $:^{8.14}$ the incidence of apnoea with the infusion was 0.25 per cent as against 30 per cent when the intermittent method was employed; tachycardia occurred in 0.5 versus 35 per cent, hypotension in 0.5 per cent against 25 per cent, hypertension in one per cent versus 25 per cent, and muscle tremors in 0.75 per cent against three percent. Furthermore, only 65 per cent of patients reached maximum score in the recovery room within $\mathbf{3 0}$ minutes when they had been submitted to intermittent injection, whereas the percentage for those who had received the continuous infusion was 77 per cent. We did not encounter any true cases of hypersensitivity nor any histamine-like reactions in our series. However, since the possibility of allergic reactions has been reported in the literature, one must warn against the use of Alfathesin in the presence of allergies.

\section{SUMMARY}

Most surgeons and hospital administrators now recognize that many surgical procedures can be done on an out-patient basis and anaesthetists have been instrumental in developing and implementing the practice of short-stay surgery. It is our opinion that general anaesthesia using enflurane and Alfathesin will increase the safety of ambulatory surgery.

\section{RÉSUMÉ}

Ce travail ayait pour but de vous présenter une revue des problêmes de l'implantation d'une unité distincte de chirurgie d'un jour. 
Dans une première partie, après avoir defini la chirurgie ambulatoire et donne sa raison d'être, nous avons parle de la sélection des patients, du type de chirurgie, du genre de prémedication, de la méthode d'anesthésie, des recommandations suggérées au patient lui-même et des critères utilises a la periode de reveil avant le congediement.

La seconde partie s'est voulue plus personnelle et nous avons successivement fait mention de notre expérience avec l'ethrane chez l'enfant et la perfusion d'Alfatesine chez l'adulte. Les résultats obtenus ont été présentes et discutes.

En conclusion, l'on se doit de retenir que l'anesthésie générale est devenue de plus en plus securitaire pour la chirurgie d'un jour.

\section{REFERENCES}

1. Rapport du Comité d'étude sur l'implantation des services ambulatoires spêcialisés. Ministère des Affaires Sociales, Québec (1976).

2. REED, W.A., BOYdeN, L.C., \& Ford, J.L. Anesthesia and operations on out-patients. Critical Care Medicine and Anesthesiology 10(3), chap. 17:335

3. SснміDт, K.F. Outpatient anesthesia. International Anesthesiology Clinics, Vol. 14. Boston. Little, Brown \& Co. (1976).
4. Bufron, S.E. Out-patient anesthesia. Refresher Courses in Ane sthesiology 2(7): 86 (1974).

5. Dawkins, O.S., Russell, E.S., adams, A., hooper, R.L., Odiakosa, C.A., \& Fleming, S.A. Intravenous Regional Anaesthesia. Can. Anaesth. Soc. J., I/(3): 243 (1964).

6. STEWARD, D.J. A trial of enflurane for paediatric out-patient anaesthesia. Can. Anaesth. Soc. J., 24(5): 603 (1977)

7. Kim, J., SMith, P., \& Jenkins, G. Massachusetts Eye and Ear Infirmary (personal communication).

8. DECHENE, J.P. Alfathesin by continuous infusion supplemented with intermittent pentazocine. Can. Anaesth. Soc. J., 24(6): 702 (1977).

9. Child, K.J., Harndy, G., Gieson, W., \& Hard, J.W. Metabolism and excretion of althesin (CT 1341) in the rat. Postgraduate Medical Journal: Steroid Anaesthesia (Suppl. 2), $48: 37$ (1972).

10. Du Callar, J., Deschodt, J. Bessou, D., \& Cabanel, P. Anesthésie à débit constant par l'association Alfathésine-Fentanyl. Annales de l'anesthésiologic Française 16: 331 (1975).

11. Rifat, K. Pentazocine in sequential analgesic anaesthesia. Brit. J. Anaesth. 44(2): 175 (1972).

12. AlDRETE, J.A. \& Krowlik, D. A. Post-anaesthetic recovery score. Anesth. Analg. 49: 924 (1970).

13. Picard, J.M., Laxenaire, M.C., \& Weber, C. Annales de l'Anesthésiologie Française 15(9): 824 (1974).

14. Dechene, J.P. Alphathesin, a new steroid anaesthetic agent. Can. Anacsth. Soc. J. 23(2): 163 (1976). 